\title{
Down-regulation of ATP-binding cassette transporter G1 expression by unmethylated CpG oligodeoxynucleotides in RAW 264.7 macrophages
}

\author{
Jeong Min Seo ${ }^{1}$, Ji-Young Lee ${ }^{2}$, Geun Eog $\mathrm{Ji}^{3}$ \\ and Ji Chang You ${ }^{1,4}$ \\ ${ }^{1}$ National Research Laboratory of Molecular Virology \\ Department of Pathology \\ The Catholic University of Korea, School of Medicine \\ Seoul 137-701, Korea \\ ${ }^{2}$ Department of Nutritional Sciences \\ University of Connecticut \\ Storrs CT 06269, USA \\ ${ }^{3}$ Department of Food and Nutrition \\ Research Institute of Human Ecology \\ Seoul National University \\ Seoul 151-742, Korea \\ ${ }^{4}$ Corresponding author: Tel, 82-2-2258-7312; \\ Fax, 82-2-2258-7790; E-mail, jiyou@ catholic.ac.kr \\ http://dx.doi.org/10.3858/emm.2011.43.9.058
}

Accepted 6 July 2011

Available Online 8 July 2011

Abbreviations: ABCA1, ATP-binding cassette transporter A1; ABCG1, ATP-binding cassette transporter G1; CpG ODN, cytidine-phosphate-guanosine oligodeoxynucleotide; LXR $\alpha$, liver $X$ receptor $\alpha$; PO, phosphodiester; PPAR $\gamma$, peroxisome proliferator activated receptor $\gamma$; PS, phosphorothioate; TLR, toll-like receptor

\begin{abstract}
We have investigated the effect of various forms of phosphodiester cytidine-phosphate-guanosine oligodeoxynucleotides (CpG ODNs) on the production of pro-inflammatory cytokines and related genes in RAW 264.7 macrophages. Treatment with the CpG ODNs increased the expression of tumor necrosis factor $\alpha$ (TNF- $\alpha$ ), IL-6, and inducible nitric oxide synthase but not interleukin-1 $\beta$ (IL-1 $\beta$ ). We also investigated the effect of CpG ODNs on the expression of ATP-binding cassette transporter A1 (ABCA1) and G1 (ABCG1) genes which are known to facilitate cholesterol efflux from macrophages for anti-atherosclerosis. CpG 2006 significantly reduced the levels of ABCG1 mRNA as determined by real-time polymerase chain reaction, whereas ABCA1 mRNA level was not changed. Western blot analysis further confirmed the reduction
\end{abstract}

of ABCG1 protein expression by CpG 2006. In addition, we also determined the protein level of peroxisome proliferator activated receptor $\gamma$ (PPAR $\gamma$ ), which is recognized as a transcriptional activator of $A B C$ transporters, was also reduced by CpG 2006. Thus, these results suggest that $A B C G 1$ is specifically down-regulated by CpG 2006 in a PPAR $\gamma$-dependent manner in macrophages.

Keywords: atherosclerosis; ATP-binding cassette transpoters; cholesterol; CpG oligonucleotide; macrophages

\section{Introduction}

All plants and animals, including humans, have innate defense systems for protection against viral and bacterial invasions. The innate immune system is initiated by pattern recognition molecules (PRMs) that recognize pathogen-associated molecular patterns (PAMPs) such as peptidoglycan, lipopolysaccharide (LPS), and unmethylated cytidine-phosphate-guanosine (CpG) DNA. Recent studies have demonstrated that immunostimulation can be induced through toll-like receptor 9 (TLR9) by synthetic $\mathrm{CpG}$ oligodeoxynucleotides (CpG ODNs) as well as bacterial DNA. To date, many studies have demonstrated that synthetic CpG ODNs containing ' $\mathrm{CpG}$ motifs' are able to activate dendritic cells, natural killer (NK) cells, monocytes, macrophages and $B$ cells, inducing the release and secretion of various cytokines and immunoglobulins (Krieg, 1995; Krug et al., 2001; Iwasaki and Medzhitov, 2004; Blaas et al., 2009; El Kebir et al., 2009; Mangsbo et al., 2009; Vollmer et al., 2009). Lately, it has been being also reported that TLRs and their signaling cascades are involved in the perpetuation of a chronic inflammatory milieu that characterizes obesity and high fat feeding (Shoelson et al., 2007; Ajuwon et al., 2009). For these reasons, safety concerns might be raised concerning the use of CpG ODNs as therapeutic agents for patients with diabetes and inflammatory arthritis as well as atherosclerosis (Zeuner et al., 2003).

It has been reported that macrophages may play a major role in atherosclerosis (Davies, 1996). 
When the function of macrophages is not properly controlled, they can trigger low-grade inflammation in the artery by producing various pro-inflammatory cytokines, chemokines and enzymes that amplify the progression of atherosclerosis. In addition to eliciting chronic low-grade inflammation, macrophages are involved in the pathological deposition of cholesterol during atherogenesis as a result of the uptake of modified low-density lipoproteins (LDLs) (van Reyk and Jessup, 1999). Macrophages with cholesterol accumulation become foam cells, a hallmark of the early atherosclerotic lesion (Rigamonti et al., 2008). ATP-binding cassette transporter $A 1$ (ABCA1) and $G 1$ (ABCG1) are known to facilitate cholesterol efflux from macrophages to extracellular acceptors such as lipid-free apolipoprotein A-I (apoA-I) and high-density lipoprotein (HDL). The ability of apoA-I and HDL to stimulate cholesterol efflux from macrophages in the arterial wall represents the first step in reverse cholesterol transport (RCT), a process that transports excess cholesterol from the periphery to the liver for ultimate excretion from the body. The role of HDL in the RCT is central to its anti-atherogenic effects (Tall et al., 2008). ABCG1 was recently shown to be capable of mediating an active efflux of cholesterol and phospholipids in macrophages (Brewer et al., 2003).

In this study, we hypothesized if CpG ODNs could be involved in regulating the expression of $A B C A 1$ or $A B C G 1$ in macrophages, as little is known about the regulation of $A B C$ transporter genes by CpG ODN. Therefore, we investigated the effectiveness of $C p G$ ODNs in a phosphodiester form (PO-ODNs), to be more biologically relevant, in the modulation of ABCA1 and ABCG1 gene expression as well as in inducing various pro-inflammatory cytokine production in RAW 264.7 murine macrophages.

\section{Results}

\section{Immuno-stimulatory effect of natural PO-formed CpG ODNs}

In order to verify first the effectiveness of the CpG ODNs used in this study in inducing alledgedly known pro-inflammatory cytokines, RAW 264.7 macrophage cells were treated with various CpG ODNs $(15 \mu \mathrm{g} / \mathrm{ml})$ for $12 \mathrm{~h}$, along with a negative control CpG $2006(-)$ and an untreated control (mock) (Figure 1A). The tumor necrosis factor (TNF)- $\alpha$ concentration in media after the treatment was measured using an enzyme-linked immunosorvent assay (ELISA). The results showed that macrophages treated with CpG 2006, PE2059,
A

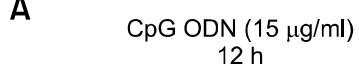

B

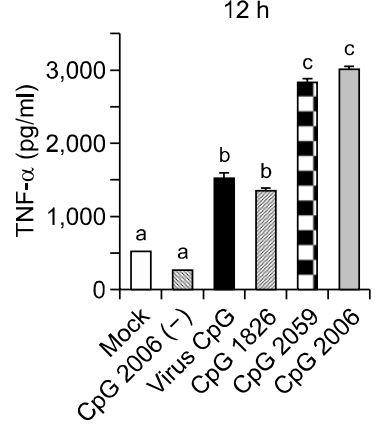

B
$24 \mathrm{~h}$
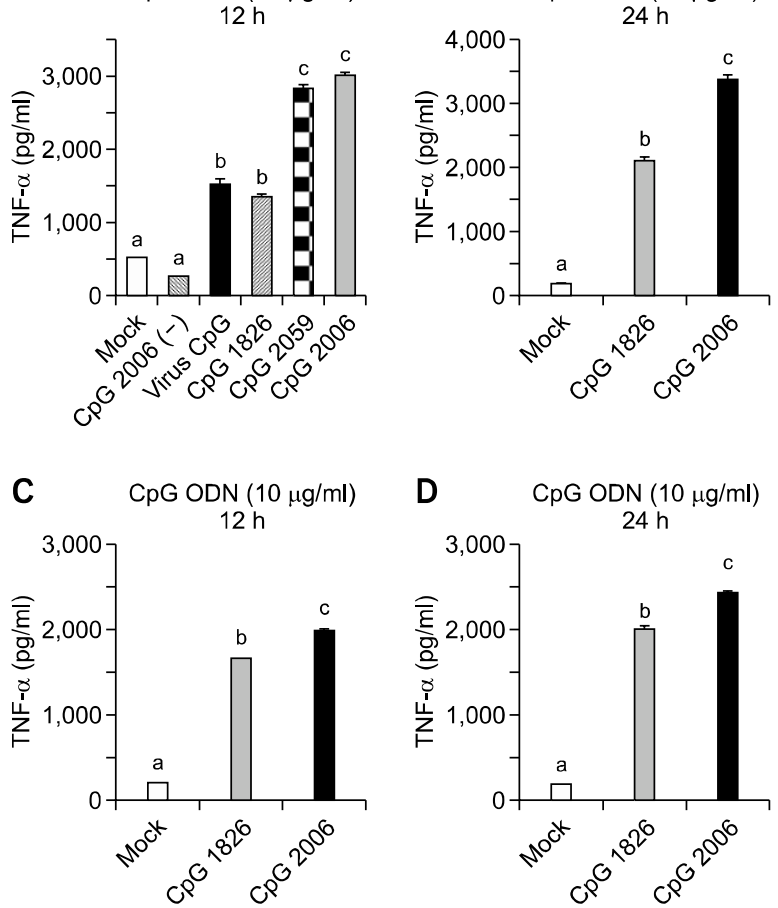

Figure 1. Expression of pro-inflammatory cytokine, TNF- $\alpha$ induced by TLR9 agonist CpG ODNs in RAW 264.7 cells. Cells were incubated with or without CpG ODNs for 12 and $24 \mathrm{~h}$. Supernatants were recovered for each time point and assayed for TNF- $\alpha$ protein secretion by ELISA. (A) Cells were treated with each CpG ODN ( $15 \mu \mathrm{mol} / \mathrm{ml})$ for $12 \mathrm{~h}$ to evaluate the effects on TNF- $\alpha$ compared with untreated (mock) and CpG 2006(-) controls. (B-D) Cells were treated with CpG 1826, which include murine CpG motifs, and CpG 2006 which includes human CpG motifs. The CpG ODNs induced secretion of TNF- $\alpha$ in a time- and dose-dependent manner. Values are means \pm standard error of the mean (SEM; $n=6$ ). Bars with different letters are significantly different $(P<0.05)$.

virus-originated $\mathrm{CpG}$ ODN (virus $\mathrm{CpG}$ ), and $\mathrm{CpG}$ 1826 all showed a significant increase in TNF- $\alpha$ secretion, compared to the mock and CpG $2006(-)$ (Figure $1 \mathrm{~A})$. Among the $\mathrm{CpG}$ ODNs that were used in this study, CpG 2006 had the greatest effect on TNF- $\alpha$ production in RAW264.7 macrophages and PE2059 showed an effect similar to that of CpG 2006. Compared with PE2059, CpG2006 has one additional nucleotide, $\mathrm{T}$, at the 3 '-terminus.

The fact that CpG 2006, which contains human CpG motif sequences GTCGTT, showed a strong immuno-stimulatory effect even in murine macrophages is consistent with previous findings observed with phosphorothioate-modified ODNs (PSODNs) in primary $B$ cell and isolated murine cardiomyocytes (Hartmann and Krieg, 2000; Hartmann et al., 2000; Knuefermann et al., 2008). Of noted interestingly, CpG 2006 elicited a significantly higher pro-inflammatory response than that of $\mathrm{CpG}$ 1826 which is generally recognized as a murine 

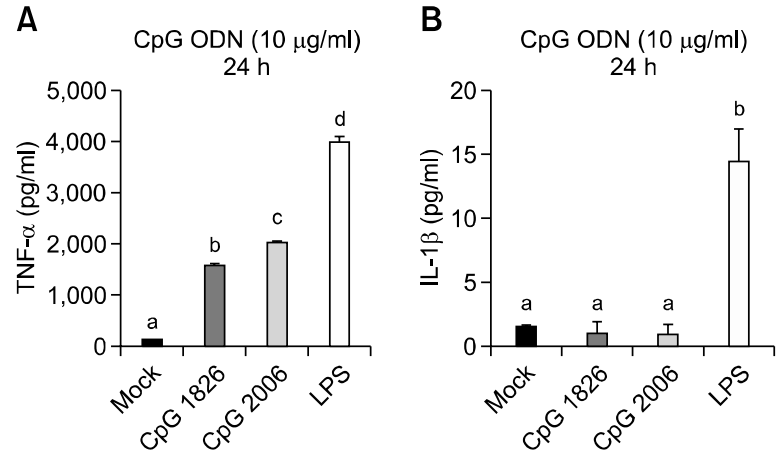

Figure 2. Comparison of TNF- $\alpha$ and IL-1 $\beta$ induction by $\mathrm{CpG} 1826$ and CpG 2006. Both CpG 1826 and CpG 2006 up-regulated TNF- $\alpha$ significantly but did not alter IL-1 $\beta$ levels compared to LPS (positive control). Cells were treated with $10 \mu \mathrm{g} / \mathrm{ml}$ of each CpG ODN or $0.1 \mu \mathrm{g} / \mathrm{ml}$ LPS for $24 \mathrm{~h}$. Supernatants were recovered and assayed for the secretion of TNF- $\alpha(A)$ and IL-1 $\beta(B)$ by ELISA.

CpG ODN. It was observed that CpG 2006 had a more prominent effect on TNF- $\alpha$ production than CpG 1826 for both cases of $12 \mathrm{~h}$ and $24 \mathrm{~h}$ treatments (Figures 1A-1D); the immunostimulatory effect of CpG 2006 was $61.4 \%$ higher than that of CpG 1826 for 24-h treatment at a concentration of $15 \mu \mathrm{g} / \mathrm{ml}$ (Figure 1B). In addition, a 24-h treatment with CpG 2006 ODN (10 $\mu \mathrm{g} / \mathrm{ml})$ (Figure 1D) showed further induction of TNF- $\alpha$ than a 12-h treatment (Figure 1C). Thus, these results demonstrate clearly that PO CpG 2006 is able to increase TNF- $\alpha$ expression in a dose- and time-dependent manner and is superior to CpG 1826 for that matter in RAW 264.7 macrophage cells.

We also compared the same immunostimulatory effect of CpG ODNs with that of LPS at a concentration of $0.1 \mu \mathrm{g} / \mathrm{ml}$. The production of TNF- $\alpha$ induced by $C p G$ ODNs was almost half of that induced by LPS (Figure 2A). In addition, CpG ODN-treated cells were markedly different from LPS-treated cells in the induction of IL-1 $\beta$ (Figure $2 \mathrm{~B}$ ); unlike TNF- $\alpha, \mathrm{IL}-1 \beta$ production measured by ELISA was not affected by CpG ODNs. The same results were also found even up to $20 \mu \mathrm{g} / \mathrm{ml}$ (data not shown). Thus, these results indicate that IL-1 $\beta$ secretion is much more sensitive to LPS than to CpG ODNs.

\section{Real-time RT-PCR analysis of the expression of pro-inflammatory genes by CpG 2006}

We measured mRNA levels of pro-inflammatory genes if characteristic of gene expression is different from that of protein levels by ELISA. Above all, we investigated the effect of CpG 2006, a human CpG ODN, and CpG 1826, a murine CpG ODN in
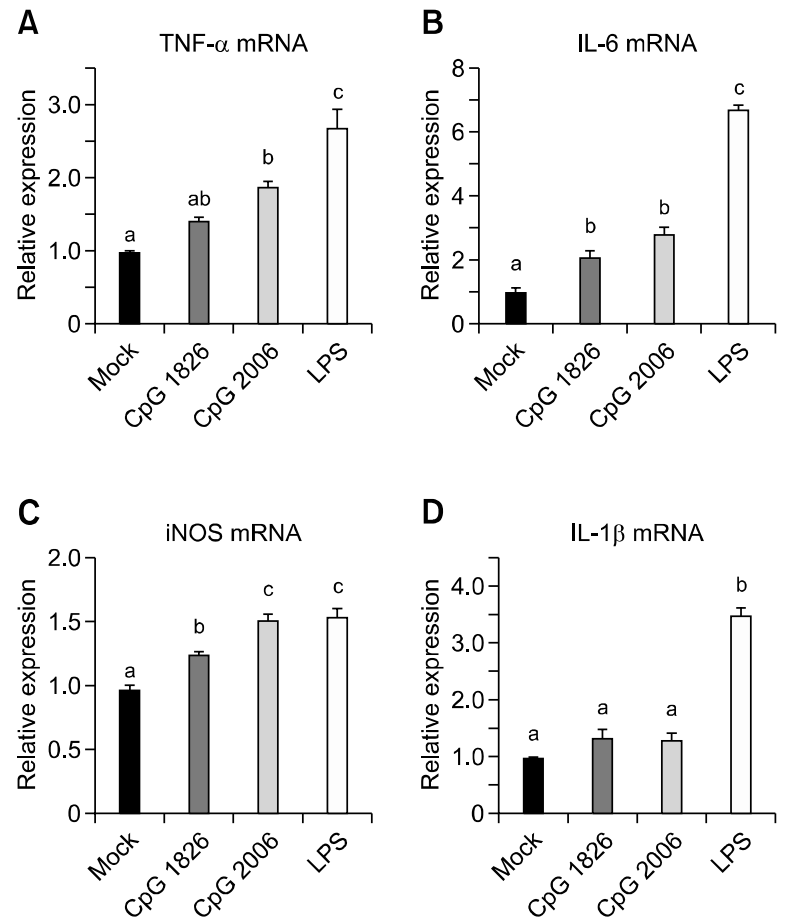

Figure 3. Transcriptional modulation of pro-inflammatory genes by $\mathrm{CpG}$ 1826 and CpG 2006. CpG 1826 and CpG 2006 induced mRNA levels of TNF- $\alpha(A)$, IL-6 (B), and iNOS (C). In contrast, the CpG ODNs did not up-regulate the mRNA level of IL-1 $\beta$ significantly (D). The mRNA levels of the indicated genes were quantified by real-time RT-PCR after treating macrophages with $10 \mu \mathrm{g} / \mathrm{ml}$ of each CpG ODN or $0.1 \mu \mathrm{g} / \mathrm{ml}$ LPS for $12 \mathrm{~h}$.

comparison. RAW 264.7 macrophages were incubated with CpG 1826 or CpG 2006 for $12 \mathrm{~h}$, and the pro-inflammatory genes TNF- $\alpha$, IL-6 were evaluated by quantitative real-time PCR (RT qPCR). Figures $3 \mathrm{~A}$ and $3 \mathrm{~B}$ show that a 12-h treatment with CpG 1826 or CpG 2006 significantly increased the expression of TNF- $\alpha$ and IL-6 mRNAs in RAW 264.7 cells compared with that in the untreated control.

We also investigated another pro-inflammatory gene, namely inducible nitric oxide synthase (iNOS), which is recognized as a marker of inflammation that alerts cells through NO production (Schindler and Darnell, 1995; Howard et al., 2010). Our results showed that $\mathrm{CpG}$ ODNs activated the iNOS gene in RAW 264.7 cells. CpG 2006 treatment induced a greater increase in the expression of iNOS gene than CpG 1826, resulting in a level similar to those induced by LPS (Figure 3C).

However, the CpG ODNs did not significantly up-regulate again the levels of IL-1 $\beta$ mRNA, which was apparently up-regulated by LPS (Figure 3D). This result in mRNA levels was consistent with that in protein levels as observed in Figure 2B. 
A

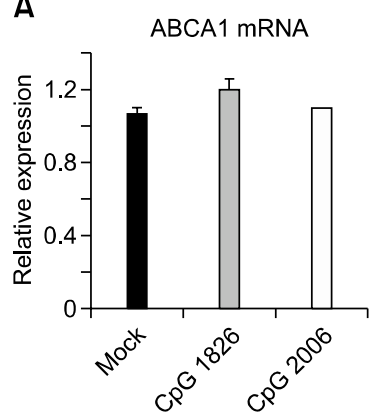

B

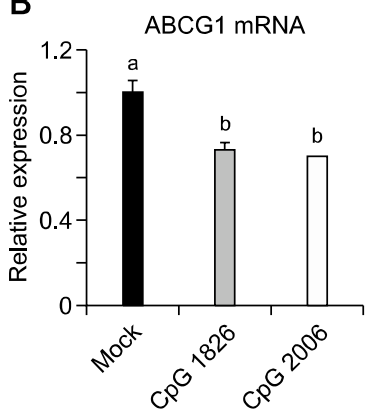

Figure 4. Down-regulation of mRNA levels of ABCG1 by CpG ODN 1826 and $C p G 2006$ without change of $A B C A 1$. The mRNA level of $A B C G 1$, but not of $A B C A 1$ was down-regulated specifically by $\mathrm{CpG}$ ODNs in RAW 264.7 cells. Cells were incubated with or without each CpG ODN (10 $\mu \mathrm{g} / \mathrm{ml}$ ) for $12 \mathrm{~h}$. The mRNA abundance of the two genes was determined by real-time RT-PCR. Values are means $\pm \mathrm{SEM}, n=3$. Bars without a common letter are significantly different, $P<0.05$.

\section{Down-regulation of ABCG1 mRNA by CpG ODNs}

Having demonstrated well that the PO CpG 2006 is able to induce pro-inflammatory cytokines, at least in murine macrophages using a cell-based assay, we next evaluated the effect of CpG 2006 along with $C p G 1826$ on expression of $A B C$ transporters to determine whether $A B C A 1$ and $A B C G 1$ are modulated according to boosting the pro-inflammatory cytokines by the CpG ODNs. RAW 264.7 macrophages were treated with a murine representative CpG 1826 and a human representative CpG 2006 for $12 \mathrm{~h}$ to determine the expression levels of the cholesterol transporter genes $A B C A 1$ and $A B C G 1$. The abundance of ABCA1 mRNA in CpG ODN-treated cells was not different from that of the mock control (Figure 4A), whereas ABCG1 mRNA levels were significantly reduced by both CpG 1826 and CpG 2006 (Figure 4B). In CpG 2006 -treated cells, the mRNA level of ABCG1 was decreased by $30 \%$.

\section{Decrease in ABCG1 and PPARg protein levels induced by CpG 2006}

As the mRNA levels of ABCG1 were reduced by $-30 \%$ after treatment with CpG 2006 and 1826, we also measured ABCG1 protein levels by Western blot analysis, using $\mathrm{CpG} 2006$ which showed the highest effect on various aspects determined thus far in this study. ABCG1 protein levels were lowered by CpG 2006 but without any change in ABCA1 protein levels. CpG 2006 treatment at concentrations of 10 and $20 \mu \mathrm{g} / \mathrm{ml}$ led to a significant reduction in ABCG1 protein levels by $-25 \%$ and $33 \%$, respectively, whereas ABCA1 protein levels were not altered, which is consistent with its mRNA levels (Figure $5 \mathrm{~A}$ ).
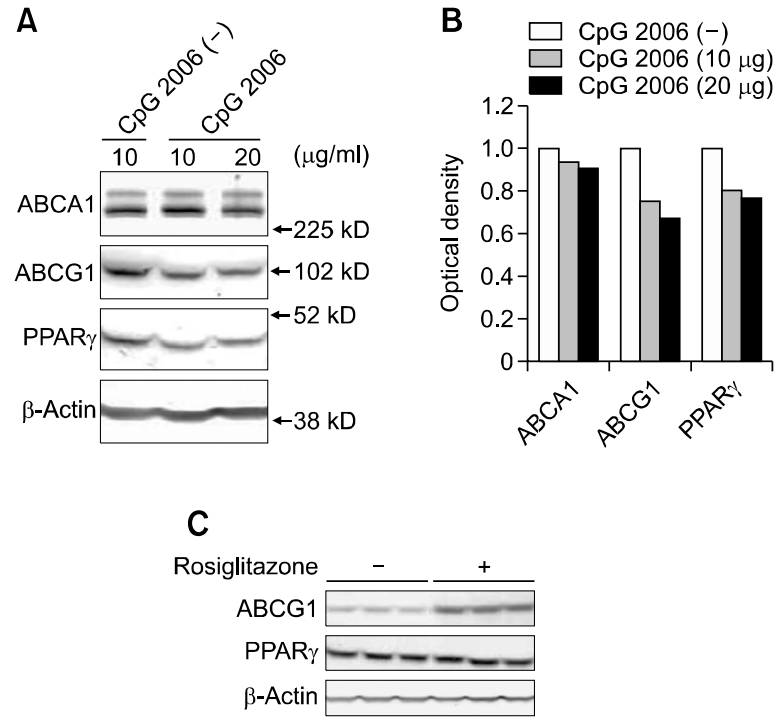

Figure 5. Reduction of $A B C G 1$ protein and its transcriptional activator PPAR $\gamma$, but not ABCA1 protein by CpG 2006. (A) CpG 2006 decreased expression of ABCG1 protein but not ABCA1 protein in RAW 264.7 macrophages. Cells were incubated with $10 \mu \mathrm{g} / \mathrm{ml}$ and $20 \mu \mathrm{g} / \mathrm{ml} \mathrm{CpG} 2006$ for $12 \mathrm{~h}$. $A B C A 1$ and $A B C G 1$ protein expression were measured by Western blot analysis using $\beta$-actin as a loading control. (B) Data are normalized to the respective expression levels in CpG 2006(-)-treated macrophages. The experiments were repeated twice, and one representative experiment is shown. (C) A PPAR $\gamma$-specific agonist, rosiglitazone induced the expression of ABCG1 protein by enhancing the activity of PPAR $\gamma$. The cells were incubated with $10 \mu \mathrm{M}$ of rosiglitazone in DMSO for $12 \mathrm{~h}$.

It was previously reported that the PPAR $\gamma$-specific agonist rosiglitazone could induce ABCG1 expression in both wild-type and $/ x r \alpha \mid \beta$ double knockout macrophages, indicating that PPAR $\gamma$-dependent regulation of $A B C G 1$ occurs independently of liver $X$ receptor $\alpha(L X R \alpha)$ (Li et al., 2004). Therefore, we investigated the effect of $\mathrm{CpG} 2006$ on protein levels of PPAR $\gamma$ and found that CpG 2006 treatment also resulted in a significant reduction of PPAR $\gamma$ protein levels by $20.0 \%$ and $23.4 \%$ at concentrations of $10 \mu \mathrm{g} / \mathrm{ml}$ and $20 \mu \mathrm{g} / \mathrm{ml}$, respectively (Figures $5 \mathrm{~A}$ and $5 \mathrm{~B}$ ). In the same experimental setting, however, treatment of rosiglitazone induced the ABCG1 expression but not PPAR $\gamma$ expression (Figure $5 \mathrm{C}$ ) as it has been reported previously (Davies et al., 2002). Thus, taken together, our results strongly suggest that the activation of TLR9 by CpG 2006 down-regulates PPAR $\gamma$, which could in turn reduce significantly the expression of ABCG1 gene, one of known PPAR $\gamma$ target genes.

\section{Discussion}

In this study, we have evaluated the effect of sev- 
eral PO-ODNs and observed that these $\mathrm{PO}$ $B-C l a s s$ ODNs boosted various immune responses in RAW 264.7 macrophages, as they increased the mRNA and protein levels of TNF- $\alpha$ cytokine both time- and dose-dependently as measured by RT qPCR and ELISA (Figures 1 and 2). And we found that other pro-inflammatory cytokines such as IL-6 and iNOS were also induced well by PO-ODNs as was reported previously with PS-ODNs which are resistant to nuclease degradation (Knuefermann et al. 2008; Zhu and Mohan, 2010).

The expression level of IL-1 $\beta$ was, however interestingly, not altered by CpG ODN compared with the mock control, whereas LPS increased IL-1 $\beta$ levels even at a low concentration of $0.1 \mu \mathrm{g} / \mathrm{ml}$ (Figure 2). Thus, it appears that CpG ODN is likely to play a milder or no influence on the level of IL-1 $\beta$ production than LPS. This difference may be explained by mechanisms of action of CpG ODN and LPS. $\mathrm{CD}^{+}{ }^{+}$T cells can be divided into types Th1 and Th2 which produce IFN- $\gamma$ and IL-4, respectively, and have counter-regulatory effects on each other based on the cytokines that they produce (Mosmann et al., 1986), although new subsets of $T$ cells, including regulatory $T$ cells and IL-17-producing Th cells, continue to be recognized (O'Shea et al., 2011). Pathogenesis by LPS is due to strong Th2 immune deviation (Mukherjee et al., 2009). However, CpG ODNs are able to inhibit the established Th2 immune responses against antigen, converting these to Th1 immune responses. TLR9 activation can also induce the expression of type I IFNs (Kitagaki et al., 2002). Furthermore, TLR4 by LPS induces both TRIF- and MyD88-dependent pathways, of which the former requires TRAM and the latter TIRAP, whereas TLR9 by CpG ODN induces a MyD88-dependent pathway that leads to activation of the constitutively expressed IRF7. TLR9 is also present in myeloid DCs and macrophages and induces IFN- $\beta$ through MyD88 and IRF1, instead of IRF3/7 (Baccala et al., 2007).

Additionally, RAW 264.7 macrophages treated with CpG ODN showed an increase in iNOS mRNA levels in addition to increased levels of cytokines such as TNF- $\alpha$ and IL-6. CpG ODNs themselves induce both IFN- $\gamma$ and antigen-specific IFN- $\gamma$ production (Kitagaki et al., 2002), while TLR4 agonists such as LPS are not able to boost IFN signaling. It has also been reported that IFN- $\gamma$ activates the signal transducer and activator of transcription factor 1 (STAT1), which activates transcription of various genes including a gene encoding iNOS in alveolar macrophages (Howard et al., 2010). Thus, our data confirm further that CpG ODNs could be distinguished from LPS by these characteristics.

Isoda et al. reported that macrophages treated with Advanced Glycation End product-Bovine Serum Albumin (AGE-BSA) reduced the expression of $A B C G 1$ but not that of ABCA1 in an LXR $\alpha$-independent manner in human macrophages, which was also found in LPS-mediated inflammation (Kaplan et al., 2002; Isoda et al., 2007). We also observed that the mRNA level of LXR $\alpha$ was not significantly different among the mock control, CpG 2006(-), and CpG 2006 (data not shown), consistent with the previous reports. Thus, we have investigated a possibility that CpG ODN could reduce the expression of ABCG1 in an LXR $\alpha$-independent manner. Our results showed that a TLR9 ligand such as CpG ODN inhibited expression of an anti-inflammatory transcription factor, PPAR $\gamma$ and also demonstrated that ABCG1 was specifically decreased by CpG 2006 in a PPAR $\gamma$-dependent, but not $L X R \alpha$-dependent manner, suggesting that $A B C A 1$ and $A B C G 1$ were differently regulated by $C p G$ ODN in macrophages, which is consistent with the previous findings obtained with the use of LPS and AGE-BSA as alluded above. The effect of rosiglitazone on ABCG1 observed in Figure $5 \mathrm{C}$ further substantiates that down-regulation of PPAR $\gamma$ by CpG 2006 is most likely related with the reduced protein level of ABCG1 at least in RAW 264.7 macrophages.

Recently, it has been characterized that ABCG1 promotes the efflux of cholesterol onto a variety of lipoprotein particles, including HDL, LDL, phospholipid vesicles, and cyclodextrin (Wang et al., 2006). $\mathrm{HDL}$ and $A B C G 1$ may play a potential role in macrophage apoptosis and inflammation in plaques (Tall et al., 2008). ABCG1 is highly expressed in macrophages and mediates the efflux of cholesterol to $\mathrm{HDL}_{2}$ (Klucken et al., 2000; Wang et al., 2004). Reduction of $A B C G 1$ leads to a decreased efflux of cholesterol from macrophage cells (Isoda et al., 2007). The implication of this finding for the first time that CpG ODNs could down-regulate ABCG1 may shed a warning of using CpG ODNs as an adjuvant in clinic or clinical trials, especially for atherosclerotic patients for long period.

In summary, we hypothesize that inflammatory stimuli such as CpG ODNs and AGE-BSA trigger certain cofactors that suppress PPAR $\gamma$ in an LXR-independent manner, while PARR $\gamma$ up-regulation inversely plays an anti-inflammatory role, resulting in maintenance of normal cholesterol levels. More detailed investigations into the correlation between TLR9 signaling and ABCA1/ABCG1 regulation in human macrophages are remained to be performed in the future. 


\section{Methods}

\section{Cell culture and treatment}

Murine RAW 264.7 macrophage cells (ATCC no. TIB-71) were maintained in RPMI 1640 containing $10 \%$ fetal bovine serum, $100 \mathrm{U} / \mathrm{ml}$ penicillin, $100 \mu \mathrm{g} / \mathrm{ml}$ streptomycin, $1 \times$ vitamins (from $100 \times$ vitamin solution, MediaTech, Manassas, $\mathrm{VA}$ ), and $2 \mathrm{mmol} / \mathrm{l} \mathrm{L-glutamine}$ in a humidified chamber at $37^{\circ} \mathrm{C}$ with $5 \%$ carbon dioxide. All cell culture supplies were purchased from MediaTech.

Cells were plated at a density of $1 \times 10^{6}$ cells in a well of 12-well plates for realtime PCR or $3 \times 10^{6}$ cells in a well of 6-well plates for Western blot analysis. When cells were allowed to incubate overnight to become approximately $90 \%$ confluent, increasing concentrations of CpG ODN (10, $15,20,30 \mu \mathrm{g} / \mathrm{ml}$ ) were added to culture medium for 12 or $24 \mathrm{~h}$, followed by collection of the supernatant for cytokine measurement and the cells were washed twice with cold PBS for RNA isolation or protein extraction. For the experiments, control cells were incubated with the same amount of sterile water. In rosiglitazone-experiment, the cells were incubated with $10 \mu \mathrm{M}$ of rosiglitazone (Cayman, Ann Arbor, $\mathrm{MI}$ ) in DMSO for $12 \mathrm{~h}$.

\section{Synthesis of single-stranded ODNs}

CpG ODNs such as ODN 2006, PE2059, ODN 1826 and virus-oriented $\mathrm{CpG}$ ODN containing $\mathrm{CpG}$ motif were synthesized from IDT (San Jose, CA). The stimulatory ODNs were CpG 1826 (5'-TCCATGACGTTCCTGACGTT-3'), Virusoriented ODN (5'-TCCATGACGTTCCTGATG-3'), PE2059 (5'-TCGTCGTTTTGTCGTTTTGTCGT-3'), CpG 2006 (5'-T CGTCGTTTTGTCGTTTTGTCGTT-3'), CpG 2006(-) (5'-TG CTGCTTTTGTGCTTTTGTGCTT-3'). CpG 2006(-) with inverted GC sequences is a negative control of CpG 2006 which contains human CpG motifs (GTCGTT). CpG ODNs were dissolved in endotoxin-free sterile distilled deionized water and were used at the indicated concentrations.

\section{Enzyme-linked immunosorbent assay (ELISA) for cytokine}

Concentrations of TNF- $\alpha$ and IL- $1 \beta$ in cell medium were determined by commercial mouse ELISA kits (eBiosciences, San Diego, CA) following the manufacturer's protocols.

\section{Total RNA isolation and real-time RT-PCR}

Reverse transcription for complementary DNA synthesis and RT qPCR analysis were performed as previously described (Rasmussen et al., 2008). Primers for TNF- $\alpha$, IL-1 $\beta$, IL-6, iNOS, ABCA1, ABCG1, and GAPDH were designed according to GenBank database using Primer Express software provided by $A B I$ (Applied Biosystems, Carlsbad, $\mathrm{CA})$. Lists of primer sequence are in Supplemental Data Table S1.

\section{Western blot analysis}

Cell lysate was prepared and Western blot analysis was performed as previously described (Rasmussen et al.,
2008), using antibodies for ABCA1 (a generous gift from Dr. John Parks at Wake Forest University School of Medicine), ABCG1 (Santa Cruz, Santa Cruz, CA), peroxisome proliferator activated receptor gamma (PPAR $\gamma$ ) (Santa Cruz) and $\beta$-actin (Sigma, St. Louis, MO). $\beta$-actin was used as a loading control to normalize the data.

\section{Statistical analysis}

ANOVA and Tukey's pairwise comparison with Welch's correction for unequal variance when appropriate were used to identify statistically significant differences of treatments with $P<0.05$ considered significant by GraphPad InStat 3 (GraphPad Software, Inc., La Jolla, CA). Data are expressed as mean \pm SEM.

\section{Supplemental data}

Supplemental Data include a table and can be found with this article online at http://e-emm.or.kr/article/article_files/ SP-43-9-04.pdf.

\section{Acknowledgements}

Seo JM designed and conducted experiments and wrote the manuscript. All authors gave comments and read and approved the final manuscript. We acknowledge Yoo Jin Lee for general reviews of the manuscript. This work was supported by Research Grants (M10863000011-08N630001110 and M10500000148-06J0000-14810) from the Korean Ministry of Science and Technology, and in part by National Science Foundation-EPSCoR grant EPS-0346476 to Lee JY.

\section{References}

Ajuwon KM, Banz W, Winters TA. Stimulation with Peptidoglycan induces interleukin 6 and TLR2 expression and a concomitant downregulation of expression of adiponectin receptors 1 and 2 in 3T3-L1 adipocytes. J Inflamm (Lond) 2009;6:8

Baccala R, Hoebe K, Kono DH, Beutler B, Theofilopoulos AN. TLR-dependent and TLR-independent pathways of type I interferon induction in systemic autoimmunity. Nat Med 2007;13:543-51

Blaas SH, Stieber-Gunckel M, Falk W, Obermeier F, Rogler G. CpG-oligodeoxynucleotides stimulate immunoglobulin A secretion in intestinal mucosal B cells. Clin Exp Immunol 2009;155:534-40

Brewer HB Jr, Santamarina-Fojo S. Clinical significance of high-density lipoproteins and the development of atherosclerosis: focus on the role of the adenosine triphosphate-binding cassette protein A1 transporter. Am J Cardiol 2003;92:10K-16K

Davies GF, McFie PJ, Khandelwal RL, Roesler WJ. Unique ability of troglitazone to up-regulate peroxisome proliferatoractivated receptor-gamma expression in hepatocytes. J Pharmacol Exp Ther 2002;300:72-7 
Davies MJ. Stability and instability: two faces of coronary atherosclerosis. The Paul Dudley White Lecture 1995. Circulation 1996;94:2013-20

El Kebir D, Jozsef L, Pan W, Wang L, Filep JG. Bacterial DNA activates endothelial cells and promotes neutrophil adherence through TLR9 signaling. J Immunol 2009;182: 4386-94

Hartmann G, Krieg AM. Mechanism and function of a newly identified $\mathrm{CpG}$ DNA motif in human primary B cells. J Immunol 2000;164:944-53

Hartmann G, Weeratna RD, Ballas ZK, Payette P, Blackwell S, Suparto I, Rasmussen WL, Waldschmidt M, Sajuthi D, Purcell RH, Davis HL, Krieg AM. Delineation of a CpG phosphorothioate oligodeoxynucleotide for activating primate immune responses in vitro and in vivo. J Immunol 2000; 164:1617-24

Howard M, Roux J, Lee H, Miyazawa B, Lee JW, Gartland B, Howard AJ, Matthay MA, Carles M, Pittet JF. Activation of the stress protein response inhibits the STAT1 signalling pathway and iNOS function in alveolar macrophages: role of Hsp90 and Hsp70. Thorax 2010;65:346-53

Isoda K, Folco EJ, Shimizu K, Libby P. AGE-BSA decreases ABCG1 expression and reduces macrophage cholesterol efflux to HDL. Atherosclerosis 2007;192:298-304

Iwasaki A, Medzhitov R. Toll-like receptor control of the adaptive immune responses. Nat Immunol 2004;5:987-95

Kaplan R, Gan X, Menke JG, Wright SD, Cai TQ. Bacterial lipopolysaccharide induces expression of ABCA1 but not ABCG1 via an LXR-independent pathway. J Lipid Res 2002;43:952-9

Kitagaki K, Jain VV, Businga TR, Hussain I, Kline JN. Immunomodulatory effects of CpG oligodeoxynucleotides on established th2 responses. Clin Diagn Lab Immunol 2002; 9:1260-9

Klucken J, Buchler C, Orso E, Kaminski WE, PorschOzcurumez M, Liebisch G, Kapinsky M, Diederich W, Drobnik W, Dean M, Allikmets R, Schmitz G. ABCG1 (ABC8), the human homolog of the Drosophila white gene, is a regulator of macrophage cholesterol and phospholipid transport. Proc Natl Acad Sci USA 2000;97:817-22

Knuefermann $P$, Schwederski $M$, Velten $M$, Krings $P$, Ehrentraut H, Rudiger M, Boehm O, Fink K, Dreiner U, Grohe C, Hoeft A, Baumgarten G, Koch A, Zacharowski K, Meyer $R$. Bacterial DNA induces myocardial inflammation and reduces cardiomyocyte contractility: role of toll-like receptor 9. Cardiovasc Res 2008;78:26-35

Krieg AM. CpG DNA: a pathogenic factor in systemic lupus erythematosus? J Clin Immunol 1995;15:284-92

Krug A, Rothenfusser S, Hornung V, Jahrsdorfer B, Blackwell S, Ballas ZK, Endres S, Krieg AM, Hartmann G. Identification of $\mathrm{CpG}$ oligonucleotide sequences with high induction of IFN-alpha/beta in plasmacytoid dendritic cells. Eur J Immunol 2001;31:2154-63

Li AC, Binder CJ, Gutierrez A, Brown KK, Plotkin CR, Pattison JW, Valledor AF, Davis RA, Willson TM, Witztum JL, Palinski W, Glass CK. Differential inhibition of macrophage foam-cell formation and atherosclerosis in mice by PPARalpha, beta/delta, and gamma. J Clin Invest 2004;114:1564-76

Mangsbo SM, Sanchez J, Anger K, Lambris JD, Ekdahl KN, Loskog AS, Nilsson B, Totterman TH. Complement activation by $\mathrm{CpG}$ in a human whole blood loop system: mechanisms and immunomodulatory effects. J Immunol 2009;183: 6724-32

Mosmann TR, Cherwinski H, Bond MW, Giedlin MA, Coffman $\mathrm{RL}$. Two types of murine helper T cell clone. I. Definition according to profiles of lymphokine activities and secreted proteins. J Immunol 1986;136:2348-57

Mukherjee S, Chen LY, Papadimos TJ, Huang S, Zuraw BL, Pan ZK. Lipopolysaccharide-driven Th2 cytokine production in macrophages is regulated by both MyD88 and TRAM. J Biol Chem 2009;284:29391-8

O'Shea JJ, Lahesmaa R, Vahedi G, Laurence A, Kanno Y. Genomic views of STAT function in CD4 ${ }^{+} \mathrm{T}$ helper cell differentiation. Nat Rev Immunol 2011;11:239-50

Rasmussen HE, Blobaum KR, Park YK, Ehlers SJ, Lu F, Lee JY. Lipid extract of Nostoc commune var. sphaeroides Kutzing, a blue-green alga, inhibits the activation of sterol regulatory element binding proteins in HepG2 cells. J Nutr 2008;138:476-81

Rigamonti E, Chinetti-Gbaguidi G, Staels B. Regulation of macrophage functions by PPAR-alpha, PPAR-gamma, and LXRs in mice and men. Arterioscler Thromb Vasc Biol 2008;28:1050-9

Schindler C, Darnell JE Jr. Transcriptional responses to polypeptide ligands: the JAK-STAT pathway. Annu Rev Biochem 1995;64:621-51

Shoelson SE, Herrero L, Naaz A. Obesity, inflammation, and insulin resistance. Gastroenterology 2007;132:2169-80

Tall AR, Yvan-Charvet L, Terasaka N, Pagler T, Wang N. HDL, $A B C$ transporters, and cholesterol efflux: implications for the treatment of atherosclerosis. Cell Metab 2008;7:365-75

van Reyk DM, Jessup W. The macrophage in atherosclerosis: modulation of cell function by sterols. J Leukoc Biol 1999;66: 557-61

Vollmer J, Krieg AM. Immunotherapeutic applications of CpG oligodeoxynucleotide TLR9 agonists. Adv Drug Deliv Rev 2009;61:195-204

Wang N, Lan D, Chen W, Matsuura F, Tall AR. ATP-binding cassette transporters $\mathrm{G} 1$ and $\mathrm{G} 4$ mediate cellular cholesterol efflux to high-density lipoproteins. Proc Natl Acad Sci U S A 2004;101:9774-9

Wang N, Ranalletta M, Matsuura F, Peng F, Tall AR. LXRinduced redistribution of ABCG1 to plasma membrane in macrophages enhances cholesterol mass efflux to HDL. Arterioscler Thromb Vasc Biol 2006;26:1310-6

Zeuner RA, Verthelyi D, Gursel M, Ishii KJ, Klinman DM. Influence of stimulatory and suppressive DNA motifs on host susceptibility to inflammatory arthritis. Arthritis Rheum 2003;48:1701-7

Zhu J, Mohan C. Toll-like receptor signaling pathwaystherapeutic opportunities. Mediators Inflamm 2010;2010: 781235 